\title{
THE ROLE OF ZIS FUND DISTRIBUTION (ZAKAT, INFAQ, ALMS) IN EMPHASIZING POVERTY LEVELS THAT AFFECT THE ECONOMY DURING THE COVID-19 PANDEMIC IN JAMBI PROVINCE
}

\author{
Paulina Lubis ${ }^{1)}$, Ary Dean Amri ${ }^{2)}$ \\ ${ }^{1,2)}$ University of Jambi \\ Corresponding author: paulina_lubis@unja.ac.id
}

\begin{abstract}
This article aims to determine the distribution of ZIS Funds (Zakat, Infaq, Alms) in suppressing poverty levels that impact the economy during the Covid-19 pandemic outbreak in Jambi province. The method used is descriptive-quantitative and data collection through literature study and documentation in interviews with 70 respondents. Data were analyzed using the Likert scale method and multiple linear regression analysis. The result is that part of the perception/understanding of religion has a positive and significant effect on income levels, partially service variables have no and insignificant effect on income levels, partially, service variables have a positive and significant effect on income levels. So, it can be concluded that the perception/understanding of religion, service, and decisions have a simultaneous (combined) and significant effect on income levels.
\end{abstract}

Keywords: ZIS Fund, Poverty Levels, Pandemic Covid-19

\section{Introduction}

The spread of the coronavirus globally or known as COVID-19, is increasingly worrying. Covid has spread rapidly throughout the world and has killed thousands of lives in more than 190 countries, from mainland China to parts of Europe, then America, including Indonesia. Not being responsive and there is an impression of being less open, the Government in giving information related to the handling of COVID-19 in Indonesia, made several parties provide several criticisms, both from abroad, such as the World Health Organization (WHO), as well as from inside of od the country itself, especially those from institutions. Research and academic circle. Until April 10, 2020, 12.43 GMT, the number of positive COVID-19 patients worldwide has reached 1,621,713 people, with several deaths of people is 97,183 people and 366,239 for people who recovered. In this regard, which announced Covid-19 as a pandemic outbreak.

Some countries have made many decisions to anticipate this case, both developed and developing countries, some policies have been issued, one of which is to take extreme policies to carry out a "lockdown" and several massive policies to prevent the spread of this virus according to their respective situations, conditions, and cultures. The policies currently being implemented by the Indonesian Government are Social Distancing or physical distancing, work from home, and finally, Large-Scale Social Restrictions (PSBB).

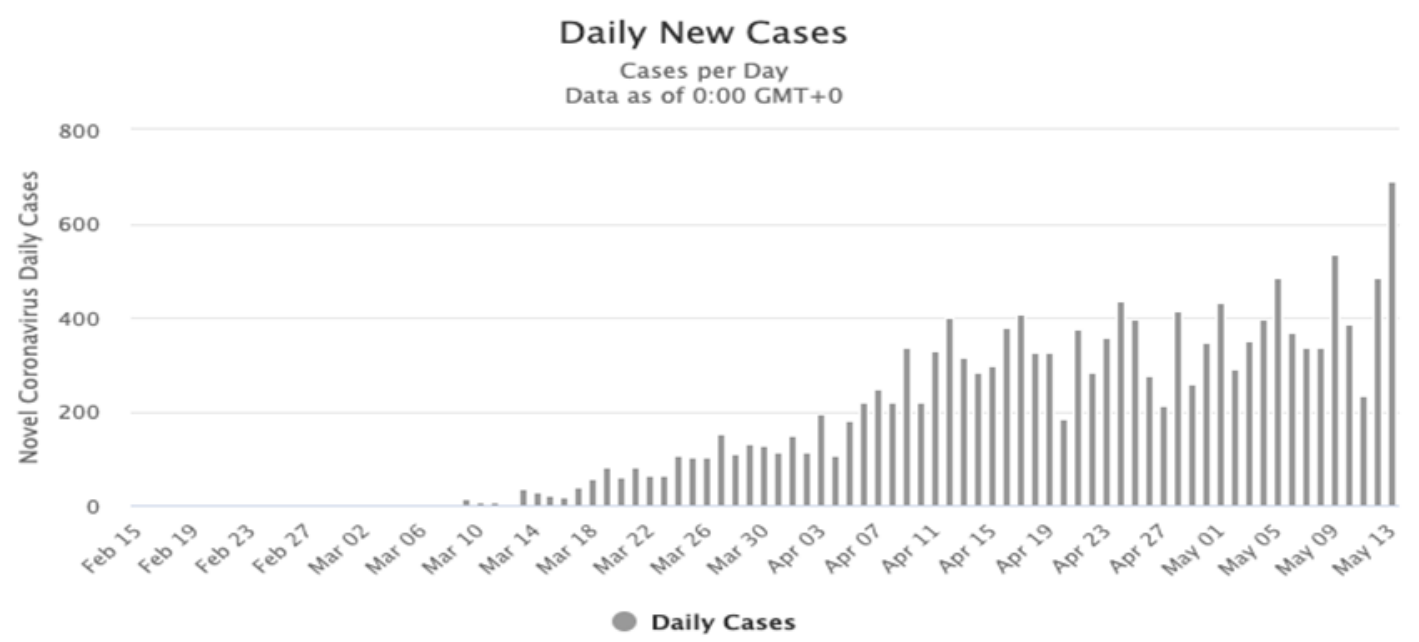

Source: https://www.worldometers.info/coronavirus/country/indonesia/, 2020

Figure 1. Number of Additional Daily Cases March 12, 2020 - May 13, 2020

The graph above shows that the number of cases per day increased from day today. On May 13, there was a significant increase in cases. This will undoubtedly give big losses to the people and Indonesia. The question that arises then is why does the Indonesian Government seem less transparent in handling the spread 
of COVID-19? The global economic turmoil that has not yet subsided and has a very significant impact on the Indonesian economy seems to be one reason why the Government seems not transparent in the delivery of formations related to COVID-19.

This chain of economic downturns will cause shocks to the fundamentals of the real economy and destroy the smooth operation of the market mechanism between supply and demand so that it can typically run and in balance. The resilience of each layer is different, so the middle to the lower-class economic community, especially the micro and informal workers with daily income, are the groups most vulnerable to the impact. The impact in the real sector will then spread to the distressed financial sector because a large number of investees will experience difficulties in paying their investors.

On April 6, 2020, the Minister of Finance of the Republic of Indonesia, Sri Mulyani, even said that the crisis caused by the coronavirus or Covid 19 is now much more complex in the appeal crisis of 1997-1998 and 2008-2009. This is because the causes of the current recession have not been detained.

One of the attention and concerns of religion and the state is poverty. Various debates about the causes of poverty, measures, and possible solutions to the community's welfare are a form of concern about the increasing number of poor people, resulting in a significant negative impact on society.

Table 1. Poverty depth index in Jambi Province Year 2002 - 2019

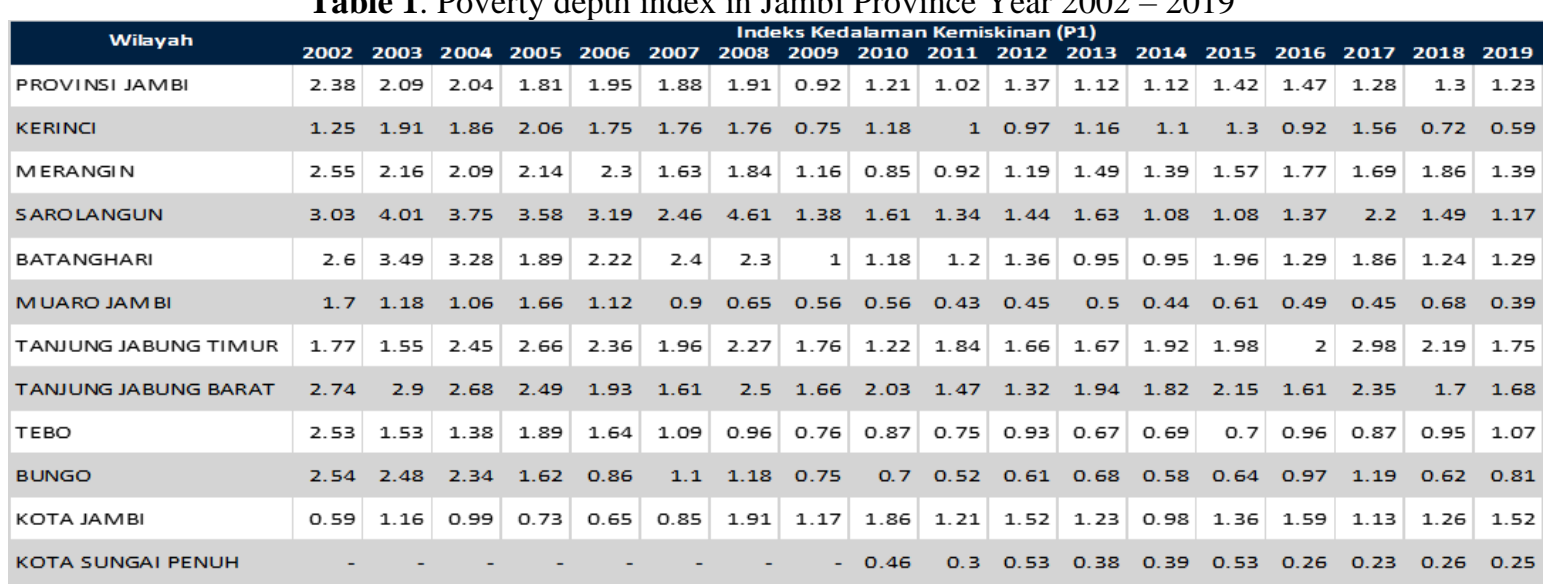

Source: Central Statistics Agency Provinsi Jambi 2020

Table 2. Percentage of Poor People in Jambi Province 2002 - 2019

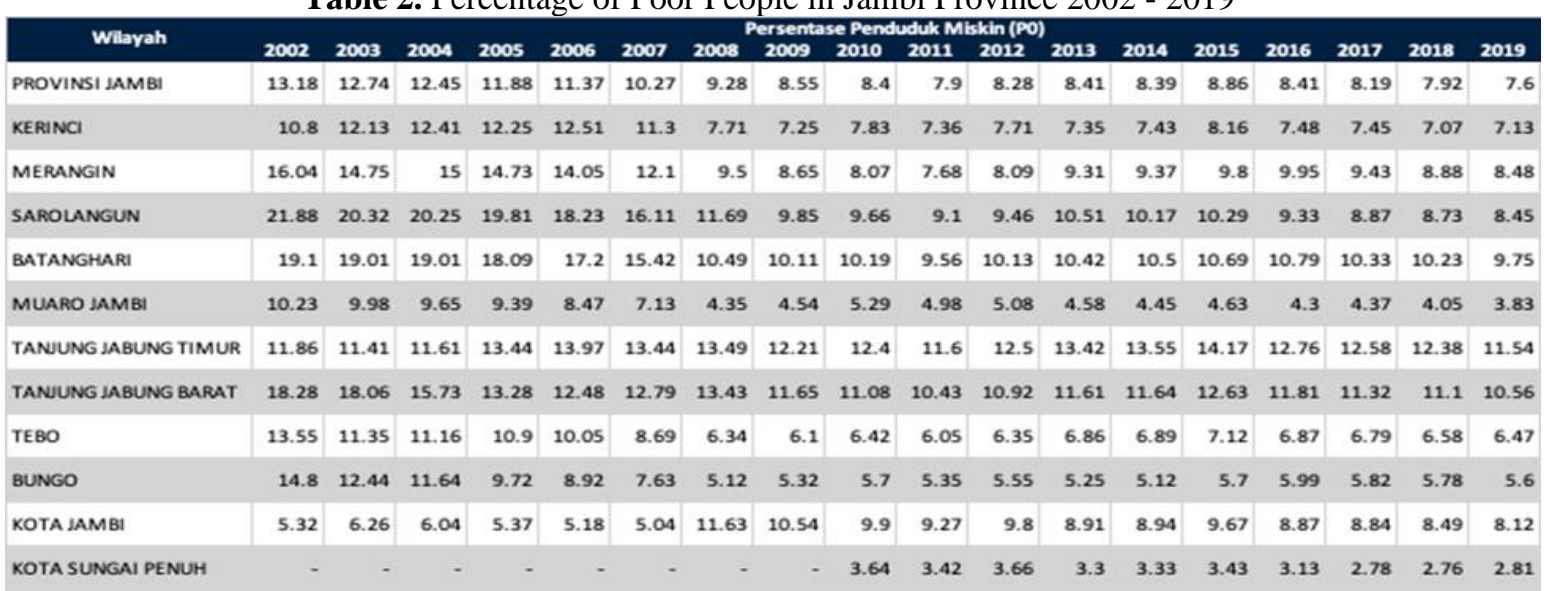

Source: Central Statistics Agency Provinsi Jambi 2020

The development of poverty level in Jambi Province in the period 2002-2019 is shown in table 1 and Table 2 above. The poverty rate includes the amount and percentage of the poor. In that period, the development of the poverty rate in Jambi city tends to decrease from 2002-2019. For the change in the highest poverty rate that is there in 2002 , therefore it can be concluded that the number of poverty that gathered by BPS Jambi city often experienced changes in the increase and decrease in the poverty rate in each year, in fear that the Covid-19 Pandemic will make the Gini ration for the poverty of the population in Jambi Province will increase.

Experts concluded that there are three causes of poverty, First, because of the limited resources owned, the second is the result of low quality of human resources, third is the lack of access to capital that causes the lack of development of businesses in the run and low production levels of both goods and services (Lapopodkk, 2012). 
In the case of the above, the Government is responsible for issuing public policies that can positively affect the improvement of economic growth and prosperity of the community without forgetting the continuity of statehood. According to Amir (2015), in a capitalist economy or conventional economy known as 2 (two) macroeconomic policies, namely fiscal policy, which is the Government's policy to influence economic activities through taxes and government spending, and monetary policy, which is the policy of the financial authority (central bank) in influencing economic activities through the amount of money supply and interest.

Indonesia's economic growth is not released from its role as a fiscal policy with a considerable effect. According to Subandi (2012), five factors affect Indonesia's economic growth: the country's financial factor, constructive fiscal policy, and financing government spending (not deficit). One of the tax functions is the budget function which is referred to as the primary function of tax or fiscal function, where tax is used as a tool to optimally put funds into the state treasury based on applicable tax laws (lee, 2020, Rengel 2020, Chugunov 2020)

In-Law No. 28 of 2007 on General Provisions and Procedures of Taxation, taxes are formally and legally defined as "mandatory contributions to the state-owned by individuals or entities that are forceful under the law by not getting direct rewards and used for state purposes for the maximum prosperity of the people" (Directorate General of Taxes). Taxes have a two-way impact on a country's economic growth like a doubleedged sword. On one side of high tax, receipts can spur a country to increase government spending that can spur the economy to create an increase in the rate of economic growth (Stoval 2020, Young 1987).

As the country with the largest Muslim population globally, Muslims can give their best role through various forms or models Filan trophies in conventional Economics and Islamic Finance. This role is expected to overcome the economic shocks that occur, and the whole community, especially Muslims, can restore the shock. Islamic Social Finance has an important position in addressing the socio-economic problems of the community and helping the Government overcome this problem. As the country with the most significant Muslim majority, it can maximize the potential of Islamic social funds managed by the Organization of Zakat, Infaq and Alms Management (OPZIS), Waqaf Management Institutions (LPW), and Microfinance Institutions or Baitul Mal wat Tamwil (BMT).

The long-term goal of zakat distribution is to provide productive business capital so that the results can be received continuously and provide economic benefits and increased income. Thus it is expected that the poor who used to be the recipients of zakat (mustahik) become givers of zakat (muzakki). The short-term purpose of zakat distribution is distributed for consumptive needs, namely to meet the basic needs of households, education, health, etc.

Fiscal policy plays an essential role in the Islamic economic system when compared to monetary policy. The prohibition on usury and the obligation on the expenditure of zakat implies the importance of the position of fiscal policy in the appeal of monetary policy. In Islam, we know the concept of zakat, infaq, alms, and waqf (ZISWAF). Zakat is an obligation to spend a portion of the income or property of a person who has fulfilled the requirements of Islam to be given to various elements of society that have been determined in Islamic law. While Infaq, alms, and waqf are voluntary expenditures that are also highly recommended in Islam. Thus ZISWAF is the element contained in fiscal policy (Naution, 2006).

Allah said in al-Qu'ans al-Baqarah verse 43 and the letter at Taubahayat 11 which reads as berkut:

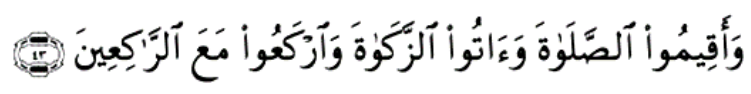

It means: and perform salat, gives zakat and ruku'lahserta people who bow down.

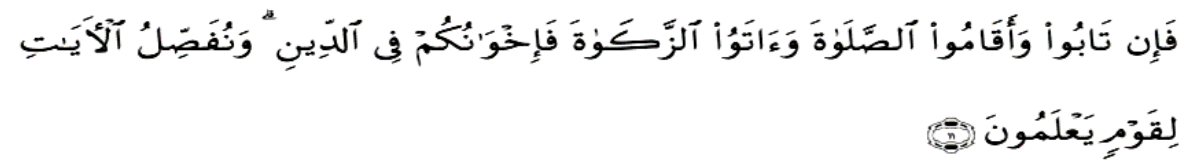

It means: if they repent, establish prayer and give zakat, then (they are) your brothers in religion. Furthermore, We explain the verses to people who know.

Paying zakat is an obligation for every Muslim who can, therefore knowing the ordinances and laws is also a necessity and obligation for every Muslim. The ability in the intention is a person who has enough wealth one mishap after the basic needs of himself and his household are met. That ability has something to do with the amount of wealth and some related to the amount of time. A nisab as a minimum standard set by TheAra' concerning quantity and haul is required concerning the deciding of property. (Khairul, 2012)

Every year, Muslims with sufficient conditions worldwide give zakat, both zakat and zakat fitrah, as an obligation. Zakat fitrah is a treasure in the form of money or rice worth 3.5 liters as a form of sanctification of the soul given to vulnerable groups such as the poor. For the views of previous scholars, zakat fitrah is actually given at the end of Ramadan so that Muslims who fall into vulnerable groups can participate in celebrating Eid al-Fitr. However, in the midst of the Covid-19 pandemic, the payment of zakat fitrah can be made faster (General Majelis Ulama Indonesia MUI). 
The rules concerning the use of zakat, infaq, and alms are contained in the Qur'an and Hadith. This fulfillment must be carried out following Islamic law and distributed to those who are entitled to receive, namely eight ashnaf (groups) as mentioned in surah At Taubah verse 60, which means:

"The Alms are meant only for the poor and the needy and those who are in charge thereof, those whose hearts are to be reconciled, and to free those in bondage, and to help those burdened with debt, and for expenditure in the Way of Allah and the wayfarer. This is an obligation from Allah. Allah is All-Knowing, All-Wise" (QS. At Taubah:60).

Zakat funds distributed and consumption can also be developed as working capital that can help increase their income ( 8 ashraf). The higher the income of the mustahik (zakat recipients), the higher the level of consumption, if the higher the consumption, the higher the demand for goods and services will also increase, automatically the production of goods and services will also increase and increase economic growth in Indonesia (Anggraini, 2016).

Direct distribution of cash assistance from zakat, infak, and alms, both from units of zakat collectors and from the community. Especially for the zakat that is cashed, the distribution can be focused on the poor directly affected by COVID-19, as one who is entitled to receive it (mustahik). This point is an Islamic Economic philanthropic scheme that has excellent potential for the economy of the community. Strengthening waqf money both with wakaftunai scheme, productive waqf and waqf linked Sukuk need to be improved. Badan Wakaf Indonesia (BWI) needs to work with Islamic financial institutions to promote this waqf scheme in order to be used in part for the construction of various waqf-based infrastructures such as Wakaf Hospital (RSW) specifically for COVID-19 victims, waqf Personal Protective Equipment (PPE), waqf masks, waqf polyclinics, Wakaf Isolation Houses (RIW), procurement of wakaf ventilators, wakaf universities and others. Waqf management must be done professionally so that that waqf can be utilized sustainably.

From the background above, this study is attractive to discuss how the influence of ZIS funds distributed by BAZNAS Jambi Province on poverty with the title " The Role of Distribution of ZIS Funds (Zakat, Infaq, Alms) in Jambi Province in Improving The Economy during the Covid-19 Pandemic Outbreak."

\section{Research Method}

There are as many as 70 samples of selected respondents, namely people in the city of Jambi. Data collection in this study was conducted by disseminating questionnaires to respondents and literature studies and documentation in interviews with respondents. In collecting data used by the authors in this study using primary data. Primary data obtained directly by disseminating questionnaires. The data were analyzed using the Likert scale and by multiple linear regression analysis methods using SPSS.

\section{Result and Discussion}

This decision was made based on a comparison of Significances values from the t-count value of each regression coefficient with a significant level that has been determined, namely with a service rate of $95 \%$ or $(\alpha=0.05) . \mathrm{N}=$ number of samples; $\mathrm{k}=$ number of dependent and independent variables. $\mathrm{df}=\mathrm{n}-\mathrm{k}=(70-4)$ $=66$ with $\alpha$ for one-party test (one-tail test), then obtained table value $=1,997$.

Tabel 1. Test Result t (Partial Test) Coefficients

\begin{tabular}{|c|c|c|c|c|c|c|}
\hline \multirow{2}{*}{\multicolumn{2}{|c|}{ Model }} & \multicolumn{2}{|c|}{$\begin{array}{l}\text { Unstandardized } \\
\text { Coefficients }\end{array}$} & \multirow{2}{*}{$\begin{array}{c}\text { Standardized } \\
\text { Coefficients } \\
\text { Beta }\end{array}$} & \multirow[t]{2}{*}{$\mathrm{T}$} & \multirow[t]{2}{*}{$\begin{array}{l}\text { It is getting } \\
\text { you out of here }\end{array}$} \\
\hline & & B & Std. Error & & & \\
\hline \multirow[t]{4}{*}{1} & (Constant) & $-7,368$ & 10,696 & &,- 689 & ,493 \\
\hline & $\mathrm{X} 1$ &, 940 &, 189 &, 572 & 4,965 &, 000 \\
\hline & $\mathrm{X} 2$ &,- 702 & ,363 &,- 250 & $-1,934$ & ,057 \\
\hline & X3 &, 512 &, 174 &, 361 & 2,935 &, 005 \\
\hline
\end{tabular}

a. Dependent Variable: Y

Source: SPSS Test Results, 2020

Based on the statistic t-test results in the table above, the direction of the coefficient of beta regression and its significance can be known. Partial test results can be seen that:

1. The religious perception/understanding variable (X1) has a calculated t of 4,965 > table 1,997 and a significance value of $0.000<0.05$. The result can be stated that partially the variable perception/understanding of religion has a positive and significant effect on income level.

2. Service variables (X2) Have a calculated $t$ of $-1,934<t$ table 1,997 and a significance value of $0.057>$ 0.05 . The result can be stated that the service variable has no effect and is not significant to the income level.

3. The decision variable (X3) Has a calculated $t$ of 2,935 > t table 1,997 and a significance value of $0.005<$ 0.05 of. The result can be stated that the service variable has a positive and significant effect on the income level. 
If the significance of $\mathrm{F}$ calculates to be less than 0.05 , then Ho is rejected, which means that independent variables simultaneously affect dependent variables. $\mathrm{N}=$ number of samples; $\mathrm{k}=$ number of dependent and independent variables.

Table 2. Test Result F (Simultaneous Test) ANOVA

\begin{tabular}{llrrrrr}
\hline \multicolumn{2}{l}{ Model } & Sum of Squares & Df & Mean Square & F & Sig. \\
\hline \multirow{4}{*}{1} & Regression & 1647,661 & 3 & 549,220 & 17,947 &, $000^{\mathrm{b}}$ \\
\cline { 2 - 7 } & Residual & 2019,782 & 66 & 30,603 & & \\
\cline { 2 - 8 } & Total & 3667,443 & 69 & & & \\
\hline
\end{tabular}

a. Dependent Variable: Y

b. Predictors: (Constant), X3, X1, X2

Source: SPSS Test Results, 2020

From the table above, it can be seen that $\mathrm{df} 1=3$, and for df $2=66$. Then obtained the value $\mathrm{F}$ table $=$ 2.74. From the $F$ test results, the calculated value of $F$ is 17,947 where it is greater than $F$ table 2.74 with a significant value of $0.000>0.05$. So it can be concluded that the perception/understanding of religion (X1), ministry (X2), and decision (X3) is simultaneously influential(together) and significant to the income level (Y).

To see how much the ability of independent variables to explain dependent variables, the determinant coefficient value (R2) obtained from the regression output can be seen in the following table:

Table 3. Test Result F (Simultaneous Test)

\begin{tabular}{lcccc}
\multicolumn{5}{c}{ Model Summary } \\
\hline Model & $\mathrm{R}$ & R Square & $\begin{array}{l}\text { Adjusted } \\
\text { R Square }\end{array}$ & $\begin{array}{c}\text { Std. The } \\
\text { error of the } \\
\text { Estimate }\end{array}$ \\
\hline 1 &, $670^{\mathrm{a}}$ &, 449 &, 424 & 5,532 \\
\hline $\begin{array}{l}\text { a. Predictors: (Constant), X3, X1, X2 } \\
\text { Source: SPSS Test Results, } 2020\end{array}$
\end{tabular}

Based on the table above, the value of $\mathrm{R} 2$ is 0.449 . This indicates that $44.9 \%$ of perception/understanding of religion, ministry, decisions contribute to income. At the same time, $55.1 \%$ who contributed to the income level were other variables not studied in this study.

\section{Conclusion}

1. Of the 70 respondents, 43 were female, and 27 were male, 26 years to 68 years. Most of them are educated the last S1 as many as 45 people, and the rest are junior high school, high school, DII, DIII, S2, and S3. Their work is varied, but the most dominant is civil servants as many as 44 people and selfemployed as many as 15 people. Their average monthly income is around $\mathrm{Rp} 2,000,000$ to $\mathrm{Rp}$ 10,000,000, some even exceed Rp 10,000,000.

2. Indicators of religious perception/understanding positively and significantly affect people's income level in Jambi Province.

3. Service indicators do not affect and are not significant to the income level of the people in Jambi Province.

4. Decision indicators have a positive and significant effect on people's income levels in Jambi Province.

\section{References}

Amir, Amri. 2015. Islamic Economics and Finance, Young Library: West Jakarta

Chugunov, I.Makohon, V.Vatulov, A.Markuts, Y. (2020) General government revenue in the system of financial regulation investment Management and Financial Innovations17(1), pp. 134-142DOI: 10.21511/imfi.17(1).2020.12

Khairul. (2012). Analysis of The Influence of Zakat On Civil Servants' Income on the Welfare of the Poor in Jambi city. Jambi: Thesis Faculty Of Economics, Jambi University.

Laptop, Jumadin, 2012. "The Influence of ZIS (Zakat, Infaq, Zakat) and Zakat Fitrah on The Decline of Poverty in Indonesia Period 1998-2010", Economic Media, Vol 20, No1, April 2012

Lee, C.L (2020) The dynamic impact of external shocks on fiscal reaction function in a small open economy. Economics and Business Letters 9(2), pp. 84-89. DOI: 10.17811/ebl.9.2.2020.84-89

Nasution, Mustafa Edwin. 2006. Introduction to Exclusive: Islamic Economy, Kencana: Jakarta.

Stovall, J.E. (2020) Equal sacrifice taxation games and Economic Behavior121, pp. 55-75. DOI: 10.1016/j.geb.2020.01.012

Young, H.P (1987) Progressive Taxation and The Equal Sacrifice Principle. Journal of Public Economics 32 (1987) 203-214. North-Holland 